\title{
INTERVENSI TAHU UNGU MAMPU MEMPERBAIKI PROFIL LIPID DARAH SUBJEK PENDERITA DIABETES MELITUS TIPE-2
}

\section{(Intervention of purple tofu improve lipid blood profile in type-2 diabetes mellitus subjects)}

\author{
Sri Novalina Amrizal ${ }^{1}$, Fransiska Rungkat Zakaria ${ }^{1 *}$, Ekowati Chasanah ${ }^{2}$, Suliantari ${ }^{1}$ \\ ${ }^{1}$ Departemen Ilmu dan Teknologi Pangan, Fakultas Teknologi Pertanian, Institut Pertanian Bogor, \\ Bogor 16680
}

${ }^{2}$ Pusat Penelitian dan Pengembangan untuk Kelautan dan Pengolahan Produk Perikanan dan Bioteknologi, Jakarta 10260

\begin{abstract}
This study aimed to determine the effect of purple tofu intervention made from black soybean seeds in improving blood lipid profile of diabetics. Intervention of purple tofu was performed for 28 days and 20 subjects selected purposively and divided into two groups, control and treated. Tofu was served in soup form as much as $85 \mathrm{~g}$. Significant improvement was identified in blood lipid profile of subjects after intervention $(p<0.05)$. Decreased lipid profile occurred in triglycerides, low density lipoprotein (LDL), total cholesterol, and high density lipoproteins (HDL) $(175.60 \pm 72.61 \mathrm{mg} / \mathrm{dl}$ to $123.70 \pm 29.50 \mathrm{mg} / \mathrm{dl}$; $133.76 \pm 47.00 \mathrm{mg} / \mathrm{dl}$ to $98.96 \pm 13.81 \mathrm{mg} / \mathrm{dl} ; 207.00 \pm 52.26 \mathrm{mg} / \mathrm{dl}$ to $154.40 \pm 50.89 \mathrm{mg} / \mathrm{dl} ; 48.90 \pm 3.24 \mathrm{mg} /$ dl to $30.80 \pm 7.09 \mathrm{mg} / \mathrm{dl}$, respectively). Overall, black soy improves blood lipid profile of type 2 diabetes mellitus subjects, involving decreased triglycerides, $L D L$, and total cholesterol levels, but has not been able to increase HDL levels.
\end{abstract}

Keywords: black soy, diabetes, lipid profile, purple tofu

\begin{abstract}
ABSTRAK
Penelitian ini bertujuan untuk mengetahui pengaruh intervensi tahu kedelai ungu yang terbuat dari biji kedelai hitam dalam memperbaiki profil lipid darah penderita diabetes. Intervensi tahu dilakukan selama 28 hari pada 20 orang subjek yang dipilih secara purposive yang dibagi menjadi dua kelompok intervensi dan kontrol. Tahu diberikan dalam bentuk sop dengan jumlah konsumsi $85 \mathrm{~g}$. Hasil penelitian menunjukkan intervensi tahu kedelai mampu memperbaiki profil lipid darah subjek $(\mathrm{p}<0,05)$. Hasil analisis trigliserida dari $175,60 \pm 72,61 \mathrm{mg} / \mathrm{dl}$ menjadi $123,70 \pm 29,50 \mathrm{mg} / \mathrm{dl}$; low density lipoprotein (LDL) dari 133,76 $\pm 47,00 \mathrm{mg} / \mathrm{dl}$ menjadi $98,96 \pm 13,81 \mathrm{mg} / \mathrm{dl}$; kolesterol total dari 207,00 $\pm 52,26 \mathrm{mg} / \mathrm{dl}$

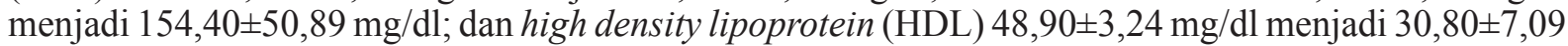
$\mathrm{mg} / \mathrm{dl}$. Berdasarkan hasil penelitian intervensi tahu ungu dapat memperbaiki profil lipid darah subjek DM tipe-2, yang mencakup penurunan kadar trigliserida, LDL dan total kolesterol, namun belum dapat meningkatkan kadar HDL darah.
\end{abstract}

Kata kunci: diabetes, kedelai hitam, profil lipid, tahu ungu

\section{PENDAHULUAN}

Diabetes melitus (DM) merupakan penyakit degeneratif, terjadi di saat tubuh tidak mampu lagi mengontrol kadar glukosa darah. Pada keadaan tersebut insulin yang dihasilkan sel $\beta$ pankreas tidak mencukupi untuk membawa glukosa masuk ke dalam sel atau insulin yang dihasilkan tidak dapat bekerja dengan semestinya sehingga glukosa berlebih di dalam darah yang disebut dengan kondisi hiperglikemia. Angka insidensi penyakit DM terus meningkat dari tahun ke tahun. Indonesia menduduki peringkat ketujuh penderita diabetes terbanyak di dunia pada tahun
2014 dan diperkirakan akan meningkat pada posisi keenam pada tahun 2040 (IDF 2015). Sebesar 95\% kasus DM berasal dari DM Tipe-2 (Rafehi et al. 2012). DM Tipe-2 disebabkan oleh gaya hidup dan pola makan yang salah yang dapat memicu obesitas dan berujung pada penyakit DM.

Obesitas dan DM merupakan sindrom metabolik atau kelainan kompleks yang memicu risiko terjadinya penyakit kardiovaskular sehingga umum di masyarakat untuk mengaitkan diabetes dengan penyakit jantung koroner yang disertai dyslipidemia aterogenik seperti rendahnya kadar kolesterol high density lipoprotein (HDLK) serta hipertigliserida (Xu et al. 2006; Bilous

\footnotetext{
"Koresponsdensi: Telp: +6287874530915, Surel: since@apps.ipb.ac.id
} 
\& Donelly 2015). Pada penderita DM terjadinya resistensi insulin, dimana glukosa tidak dapat diubah menjadi energi sehingga untuk mendapatkan energi, lemak dipecah melalui mekanisme lipolisis. Hasil akhir dari pemecahan lemak adalah asam lemak yang banyak dalam darah dibawa ke hati untuk diubah menjadi trigliserida dan kolesterol, yang akan memicu dislipidemia (Koba \& Hirano 2011; Effendi 2013).

Penerapan pola hidup sehat dengan memperbaiki pola makan yang sehat dan seimbang merupakan upaya pencegahan komplikasi dari penyakit DM. Pangan sehat yang diperlukan pada diet pengendalian DM adalah pangan dengan indeks glikemik (IG) yang rendah, cukup protein, serat, dan komponen aktifnya (Zakaria 2015). Tahu merupakan salah satu pangan yang tepat untuk dikonsumsi penderita diabetes karena memiliki kriteria tersebut, selain itu tahu memiliki efek mengenyangkan (Williamson et al. 2006; Triandita et al. 2016).

Tahu ungu terbuat dari kedelai hitam yang memiliki warna ungu pucat. Kedelai hitam memiliki keunggulan dari segi komponen aktifnya. Menurut Xu dan Chang (2008), kandungan total flavonoid kedelai hitam 6 kali lebih banyak dan aktivitas antioksidannya 15 kali lebih tinggi dibanding kedelai kuning. Selain itu, total antosianin kedelai hitam juga cukup tinggi sebesar $365,8 \mu \mathrm{l} / \mathrm{g}$ (Irwanto et al. 2016), sementara antosianin tidak terdeteksi pada kedelai kuning. Selain tingginya jumlah komponen bioaktif pada kedelai hitam, kapasitas antioksidan yang terkandung juga cukup tinggi, yaitu sebesar 45,27 $\mu \mathrm{g}$ AEAC (Zakaria et al. 2016). Tingginya kapasitas antioksidan dapat meredam radikal bebas pada penderita DM yang mana radikal bebas merupakan pemicu peroksidasi lemak yang dapat memperparah kondisi dislipidemia. Tujuan penelitian ini adalah untuk memperbaiki kondisi dislipidemia dengan penurunan kolesterol total, trigliserida, kolesterol LDL dan peningkatan kolesterol HDL subjek diabetes melitus tipe-2 dengan intervensi tahu ungu.

\section{METODE}

\section{Desain, tempat, dan waktu}

Desain penelitian ini adalah eksperimental semu (Quasi Experimental). Penelitian dilaksanakan bulan Oktober 2014-Desember 2015 dan dilakukan di klinik dr. Katili Dramaga Bogor, Laboratorium Biokimia Departemen Ilmu dan Teknologi Pangan IPB, serta Laboratorium Penyakit Hewan Fakultas Kedokteran Hewan IPB.

\section{Jumlah dan cara pengambilan subjek}

Perhitungan jumlah subjek menggunakan rumus uji beda Lameshow et al. 1997 dari ha- sil penelitian (Dewi et al. 2010; Triandita et al. 2016; Putri et al. 2016), dengan jumlah subjek (n) dihitung berdasarkan rumus:

$$
\mathrm{n}=2(\mathrm{~S})^{2}(\mathrm{Z} \alpha+\mathrm{Z} \beta)^{2}:\left(\mathrm{X}_{1}-\mathrm{X}_{2}\right)^{2}
$$

Keterangan :

$\mathrm{n}=$ jumlah subjek

$\mathrm{S}=$ standar deviasi $=42 \mathrm{mg} / \mathrm{dl}$

$\mathrm{Z} \alpha=1,64(\alpha=5 \%)$

$\mathrm{Z} \beta=1,28(\beta=10 \%)$, power of test

$\mathrm{X}_{1}=$ mean kadar glukosa darah intervensi $=110 \mathrm{mg} / \mathrm{dl}$

$\mathrm{X}_{2}=$ mean kadar glukosa darah sebelum intervensi $=170 \mathrm{mg} / \mathrm{dl}$

Berdasarkan rumus, diperoleh nilai $\mathrm{n}=$ 8,36 dengan power of test $(\mathrm{Z} \beta)$ adalah $5 \%$, maka jumlah $n=8,77$ atau setara dengan 9 . Artinya jumlah subjek yang akan digunakan adalah sebanyak 9 orang, namun penggunaan jumlah subjek sebanyak 10 orang dilakukan dengan pertimbangan kemungkinan ada yang tidak meneruskan sampai selesai intervensi. Pengumpulan subjek dilakukan dengan pemeriksaan glukosa darah di sekitar desa Babakan Raya dan Ciherang.

Intervensi dilakukan terhadap subjek dengan kriteria inklusi usia 25-65 tahun, memiliki kadar glukosa darah puasa (GDP) pada darah kapiler $\geq 100 \mathrm{mg} / \mathrm{dl}$ atau memiliki kadar glukosa darah sewaktu pada darah kapiler $\geq 200 \mathrm{mg} / \mathrm{dl}$. Kriteria eksklusi adalah terdapat gangren atau penyakit kronis lainnya, dalam keadaan hamil, serta sedang menjalani terapi insulin secara rutin. Penelitian ini telah mendapatkan persetujuan komisi etik dari Unika Atma Jaya No 576/III/ LPPM-PM.10.05/07/2014.

\section{Bahan dan alat}

Bahan yang digunakan adalah biji kedelai hitam varietas Cikuray dari Lampung. $\mathrm{CaSO}_{4}$ sebagai penggumpal tahu. Bahan yang digunakan untuk analisis kolesterol total, trigliserida, HDL dan LDL yaitu sampel plasma darah, enzim Cholesterol-Liquizyme GPOP-PAP, enzim Triglyceride-Liquizyme GPO-PAP, reagen HDL-Cholesterol, dan EDTA. Pengujian dilakukan dengan metode kolorimetri CHOD-PAP enzimatis menggunakan Microlab 300 (Vital Scientific) dan dibaca pada panjang gelombang $546 \mathrm{~nm}$ kolorimetri CHOD-PAP enzimatis.

\section{Tahapan penelitian}

Pembuatan tahu ungu. Proses pembuatan tahu ungu mengikuti Zakaria et al. (2016) yang diawali dengan proses sortasi kedelai hitam varietas Cikuray, pencucian hingga bersih, perendaman selama 12 jam dengan perbandingan air : kedelai (3:1), penirisan, penggilingan menggunakan air bersuhu $75^{\circ}-85^{\circ} \mathrm{C}$ : kedelai $(8: 1)$, 
perebusan bubur kedelai hitam pada suhu $105^{\circ} \mathrm{C}$ selama 10 menit, penyaringan 100 mesh dan dihasilkan susu kedelai. Susu kedelai yang didapatkan digumpalkan dengan $2.2 \% \mathrm{CaSO}_{4}$ pada suhu $70^{\circ}-85^{\circ} \mathrm{C}$ diaduk perlahan hingga terjadi pemisahan whey, selanjutnya curds tahu dipres selama 15-20 menit untuk membentuk tekstur tahu yang padat, tahu dipotong dan direndam dalam air dingin $5^{\circ} \mathrm{C}$. Terakhir dilakukan perebusan hingga mendidih dan didapatkan tahu matang.

Intervensi produk. Intervensi tahu ungu dilakukan selama 28 hari. Tahu mentah direbus hingga matang, ditimbang sebanyak $85 \mathrm{~g}$ dengan penyajian ditambah dengan kuah sop sebanyak $200 \mathrm{ml}$. Tim peneliti mendampingi subjek saat mengonsumsi tahu pada 3 hari pertama intervensi untuk memastikan bahwa seluruh tahu benarbenar dikonsumsi oleh subjek. Selain itu, dilakukan evaluasi penerimaan produk serta dampak terhadap kesehatan melalui diskusi dan pengamatan visual setiap minggu.

Pengambilan darah. Pengambilan darah dilakukan sebanyak dua kali yaitu pada hari ke-0 (sebelum intervensi) dan hari ke-28 (setelah intervensi) oleh petugas medis klinik dr. Katili. Darah diambil sebanyak $8 \mathrm{ml}$ menggunakan syiringe dan ditampung pada vacutainer berisi antikoagulan EDTA.

Analisis profil lipid. Kadar kolesterol total (TC) serum, kadar lipoprotein-kolesterol tinggi (HDL) dan trigliserida (TG) diukur dengan metode uji fotometri enzimatik CHODPAP menggunakan KIT komersial DiaSys (DiaSsys Diagnostic Systems GmbH AlteStrasse 9 65558 Holzheim Jerman), sedangkan kolesterol lipoprotein densitas rendah (LDL) diperoleh dari perhitungan dengan menggunakan rumus $\mathrm{LDL}=$ TC-HDL- (TG / 5) (Shrivastava et al. 2013).

\section{Pengolahan dan analisis data}

Indeks masa tubuh dikategorikan berdasarkan WHO (2006) yaitu kurus $(<18.5 \mathrm{~kg} /$ $\left.\mathrm{m}^{2}\right)$, normal $\left(18.5-24.9 \mathrm{~kg} / \mathrm{m}^{2}\right)$, lebih $(\geq 25 \mathrm{~kg} /$ $\left.\mathrm{m}^{2}\right)$, dan obes $\left(\geq 30 \mathrm{~kg} / \mathrm{m}^{2}\right)$. Kadar trigliserida dikategorikan normal dengan nilai $70-150 \mathrm{mg} /$ dl. Kadar LDL dikategorikan menjadi normal apabila $<150 \mathrm{mg} / \mathrm{dl}$. Data profil lipid darah (TG, HDL, LDL, dan Kolesterol) subjek sebelum dan sesudah intervensi dianalisis menggunakan uji $t$ berpasangan pada tingkat kepercayaan $95 \%$. Analisis statistik dilakukan dengan menggunakan perangkat lunak IBM SPSS Statistic 20.

\section{HASIL DAN PEMBAHASAN}

\section{Karakteristik subjek}

Subjek terdiri atas dua kelompok perlakuan yaitu intervensi dan kontrol. Kelompok intervensi terdiri atas dua orang subjek laki-laki dan delapan orang subjek perempuan, sedangkan subjek kontrol terdiri atas tiga orang laki-laki dan tujuh orang perempuan. Sebanyak enam orang subjek pada kelompok intervensi memiliki status gizi normal, dua orang preobesitas, dan dua orang obes. Untuk kelompok kontrol, sebanyak empat orang memiliki status gizi normal, empat orang preobesitas, dan dua orang obes. Menurut Yulianti et al. (2014), prevalensi perempuan yang menderita diabetes lebih tinggi dibandingkan laki-laki karena aktivitas perempuan yang tidak sebanyak laki-laki sehingga glukosa dalam darah tidak banyak digunakan untuk menghasilkan energi. Selain itu, subjek dengan kelebihan berat badan (obesitas) berisiko dua kali lipat atau lebih menderita diabetes dari berat badan normal (Akter et al. 2014).

\section{Profil lipid subjek DM tipe-2}

Tabel 1 menunjukkan bahwa terdapat perubahan rata-rata profil lipid subjek sebelum dan setelah intervensi. Kadar trigliserida, LDL, HDL, dan total kolesterol pada kedua kelompok (intervensi-kontrol) mengalami penurunan dari keadaan awal hingga setelah intervensi. Perbaikan profil lipid subjek sejalan dengan penurunan kadar glukosa secara signifikan $(\mathrm{p}<0,05)$ pada kelompok intervensi dari hari ke-0 hingga ke-28.

Kadar trigliserida. Uji $\mathrm{t}$ berpasangan menunjukkan bahwa terdapat penurunan kadar trigliserida yang signifikan yaitu sebesar $175,60 \pm 72,61 \mathrm{mg} / \mathrm{dl}$ menjadi $123,70 \pm 29,50 \mathrm{mg} /$ $\mathrm{dl}(\mathrm{p}<0.05)($ Tabel 1). Terjadinya penurunan trigliserida pada darah subjek intervensi menunjukkan bahwa konsumsi tahu ungu mampu menurunkan kadar trigliserida darah. Chang et al. (2008) menyatakan bahwa konsumsi kedelai pada subjek diabetes mampu menurunkan kadar trigliserida secara signifikan melalui mekanisme serat pangan larut kedelai yang mampu memperlambat penyerapan glukosa dan asam lemak dari usus halus, sehingga ketersediaan substrat untuk sintesis trigliserida berkurang. Hal ini juga sesuai dengan penelitian Tungland dan Meyer (2002), dimana serat pangan lebih menurunkan kadar trigliserida. Adapun kandungan serat pangan larut pada tahu ungu pada penelitian ini adalah sebesar $4,33 \%$.

Kadar Low Density Lipoprotein (LDL). LDL yang berlebihan di dalam darah sangat berbahaya. Jumlah LDL yang terlalu banyak menyebabkan kondisi dislipidemia yang memicu terjadinya penyakit kardiovaskular, aterosklerosis (Reynold et al. 2006). Tabel 1 menunjukkan bahwa terdapat penurunan kadar LDL subjek intervensi yang signifikan sebesar $133,76 \pm 47,00$ $\mathrm{mg} / \mathrm{dl}$ menjadi $98,96 \pm 13,81 \mathrm{mg} / \mathrm{dl}(\mathrm{p}<0,05)$. Hal 
ini menunjukkan bahwa konsumsi tahu ungu mampu menurunkan kadar LDL pada subjek DM tipe-2.

Terjadinya penurunan kadar LDL pada subjek intervensi diduga karena pengaruh dari kandungan protein, serat, dan antioksidan pada tahu ungu. Menurut Palanisamy et al. (2008) berdasarkan hasil penelitian di berbagai populasi di banyak negara menunjukkan bahwa protein kedelai dapat menurunkan kolesterol plasma, triasilgliserol, glukosa darah, dan berperan sebagai antioksidan yang potensial serta memperbaiki fungsi endothelial koroner. Menurut Ulbritch dan Saemon (2010) bahwa diet dengan penambahan protein kacang kedelai dalam makanan cukup dapat menurunkan kadar LDL sampai 10\%.

Protein kedelai memiliki komponen peptida seperti $\beta$-conglycinin atau $7 \mathrm{~s}$ globulin dan glycinin atau 11s globulin yang dapat menurunkan LDL melalui mekanisme peningkatan sekresi asam empedu dan penghambatan absorbsi kolesterol dari makanan. Peptida dapat meningkatkan aktivitas reseptor LDL dan mendegradasi LDL di sel hepar sehingga menyebabkan penurunan kadar LDL dalam darah (Slamet 2011). Selanjutnya, flavonoid seperti isoflavon dalam kedelai mampu menghambat aktivitas enzim 3-hidroxy 3-methylglutaryl Co-A yang berperan dalam penghambatan sintesis kolesterol serta enzim acyl Co-A cholesteryl acil transferase yang berperan dalam penurunan esterifikasi kolesterol pada usus dan hati. Selain itu, flavonoid mampu mengikat kolesterol LDL akibat sifat flavonoid yang lipofilik. Kemampuan tahu ungu dalam meningkatkan kapasitas antioksidan berperan dalam penurunan kadar LDL darah subjek, berdasarkan penelitian Zakaria et al. (2016) bahwa terjadi peningkatan kapasitas antioksidan plasma darah penderita DM tipe-2 sebesar 7,26\%. Kadar LDL pada kelompok kontrol mengalami penurunan yang tidak nyata $(p>0,05)$. Berdasarkan penelitian, terlihat bahwa konsumsi tahu ungu mampu menurunkan kadar LDL darah pada subjek DM tipe-2, terlihat secara statistik perubahan yang nyata $(\mathrm{p}<0,05)$ berdasarkan uji Mann Whitney.

Kadar High Density Lipoprotein (HDL).

Kadar HDL normal di dalam darah berkisar 35-55 $\mathrm{mg} / \mathrm{dl}$. Semakin tinggi kadar HDL semakin baik dalam menekan jumlah kolesterol dalam darah, namun dari hasil penelitian terjadi penurunan kadar HDL pada masing-masing kelompok, tetapi dalam kisaran yang normal kadar HDL darah.

Uji $\mathrm{t}$ berpasangan menunjukkan bahwa terdapat penurunan nilai HDL pada subjek intervensi secara signifikan dari 48,90+3,24 mg/ dl menjadi $30,80, \pm 7,09 \mathrm{mg} / \mathrm{dl}(\mathrm{p}<0,05)$ (Tabel 1). Sementara itu, pada kelompok kontrol terjadi penurunan pada kadar HDL darah subjek sebesar 41,60+6,67 mg/dl menjadi 39,60+9,95 mg/dl, namun tidak signifikan secara statistik $(\mathrm{p}>0,05)$.

Obesitas merupakan gangguan metabolisme yang menyebabkan terjadinya peningkatan kadar LDL dan penurunan HDL. Peningkatan kadar HDL terjadi melalui peningkatan jumlah Apolipoprotein A-1 yang merupakan prekusor pembentukan HDL. Tahu ungu yang terbuat dari bahan dasar kedelai hitam memiliki kandungan flavonoid yang dapat meningkatkan jumlah Apolipoprotein A-1. Apolipoprotein A-1 bertugas sebagai kofaktor enzim bagi LCAT dan sebagai ligan interaksi dengan reseptor lipoprotein dalam jaringan pada HDL. Peningkatan Apolipoprotein A-1 diharapkan akan meningkatkan kadar HDL. Rucita (2012) menyatakan bahwa konsumsi yogurt kedelai hitam pada pria penderita dislipidemia sebanyak $225 \mathrm{ml}$ selama 21 hari dapat meningkatkan kadar HDL. Namun, konsumsi tahu ungu selama 28 hari belum mampu meningkatkan kadar HDL subjek DM tipe-2. Hasil ini sesuai dengan penelitian Chang et al. (2008) yang menunjukkan bahwa konsumsi kedelai pada subjek diabetes tidak menunjukan perubahan yang nyata terhadap peningkatan kadar HDL. Meningkatkan kadar HDL tidak semudah menurunkan

Tabel 1. Profil lipid subjek DM tipe 2 kelompok intervensi dan kontrol

\begin{tabular}{|c|c|c|c|}
\hline Profil lipid & Sebelum intervensi (Hari ke-0) & Setelah intervensi (Hari ke-28) & $p$ \\
\hline \multicolumn{4}{|l|}{ Trigliserida $(\mathrm{mg} / \mathrm{dl})$} \\
\hline Intervensi & $175,6 \pm 72,61$ & $123,7 \pm 29,50$ & $\mathrm{p}<0,05$ \\
\hline Kontrol & $236,1 \pm 86,45$ & $184,7 \pm 126,57$ & TS \\
\hline \multicolumn{4}{|c|}{ Kolesterol total (mg/dl) } \\
\hline Intervensi & $207,4 \pm 52,6$ & $154,4 \pm 50,89$ & $\mathrm{p}<0,05$ \\
\hline Kontrol & $206,0 \pm 76,51$ & $184,1 \pm 42,45$ & TS \\
\hline \multicolumn{4}{|c|}{ LDL-kolesterol (mg/dl) } \\
\hline Intervensi & $133,76 \pm 47,00$ & $98,96 \pm 45,83$ & $\mathrm{p}<0,05$ \\
\hline Kontrol & $117,16 \pm 48,73$ & $107,56 \pm 49,07$ & TS \\
\hline \multicolumn{4}{|c|}{ HDL-kolesterol (mg/dl) } \\
\hline Intervensi & $48,9 \pm 3,24$ & $30,8 \pm 7,09$ & $\mathrm{p}<0,05$ \\
\hline Kontrol & $41,06 \pm 6,67$ & $39,6 \pm 9,95$ & TS \\
\hline
\end{tabular}

Keterangan: Terdapat perbedaan signifikan berdasarkan uji t berpasangan $(\mathrm{p}<0,05)$; TS=tidak signifikan. 
kolesterol total, karena dibutuhkan jangka waktu yang lebih panjang.

Penurunan kadar HDL dapat disebabkan oleh kebiasaan merokok, rendahnya aktivitas fisik, asupan karbohidrat yang tinggi, dan penggunaan obat-obatan. Selama penelitian telah dilakukan pengendalian dengan edukasi yang diberikan setiap hari sejalan dengan pemberian tahu ungu tiap harinya, namun tidak semua subjek disiplin, mengingat banyak dari subjek berusia lanjut di atas 50 tahun yang mengakibatkan susah melakukan aktivitas fisik yang cukup. Rendahnya aktivitas fisik menyebabkan penurunan kadar HDL. Diet sehat, aktivitas fisik secara teratur, menjaga berat badan normal dan menghindari tembakau dapat mencegah atau memperlambat terjadinya DM-tipe 2 (WHO 2015). Meningkatkan kadar HDL lebih sulit dibandingkan menurunkan komponen kolesterol, LDL, dan TG di dalam darah. Meskipun, usaha yang sudah cukup maksimal dalam menghindari makanan dengan kandungan kolesterol tinggi dan memperbanyak konsumsi makanan yang mampu meningkatkan HDL, namun belum terjadi peningkatan HDL pada subjek intervensi tahu ungu.

Kadar total kolesterol. Total kolesterol plasma berperan dalam mempercepat terjadinya penyakit kardiovaskular seperti aterosklerosis yang merupakan komplikasi utama jangka panjang DM. Pada keadaan DM yang sudah sangat akut, sintesis kolesterol mengalami penurunan, sehingga terjadi defisiensi protein yang akan melemahkan badan (Nelson et al. 2012). Konsumsi tahu ungu diharapkan mampu menurunkan kadar total kolesterol pada subjek DM tipe-2.

Tabel 1 menunjukkan bahwa hasil penelitian selama 28 hari pada kelompok intervensi tahu ungu menunjukkan penurunan nilai total kolesterol secara signifikan $(\mathrm{p}<0,05)$ yaitu sebelum dan sesudah sebesar 207,00 $\pm 52,26 \mathrm{mg} / \mathrm{dl}$ menjadi $154,40+50,89 \mathrm{mg} / \mathrm{dl}$. Kelompok kontrol juga mengalami penurunan pada total kolesterol darah subjek, walaupun secara statistik tidak signifikan ( $>0,05)$ sebesar 206,00+76,51 $\mathrm{mg} / \mathrm{dl}$ menjadi $184,10 \pm 42,45 \mathrm{mg} / \mathrm{dl}$.

Terjadinya penurunan total kolesterol pada subjek tahu ungu diduga karena kandungan antioksidan yang cukup banyak dalam jumlah yang cukup tinggi dalam tahu ungu, antioksidan berperan dalam penurunan kadar kolesterol. Antioksidan membantu dalam mencegah terjadinya proses oksidasi lemak. Komponen bioktif seperti antosianin dalam kedelai mampu memperbaiki status antioksidan dengan menekan pembentukan malonaldehida, memperbaiki level superoksida dismutase (SOD) dan katalase sebagai enzim-enzim antioksidan pada tikus diabetes (Nizamutdinova et al. 2009). Isoflavon dan an- tosianin memiliki kekuatan dalam menghambat peroksidasi lipid, menangkap radikal bebas, dan menghambat kerusakan jaringan. Berdasarkan uji Mann Whitney, setelah 28 hari antara subjek kontrol dan intervensi secara statistik tidak signifikan $(p>0,05)$ terhadap kadar total kolesterol. Ini sesuai dengan yang diungkapkan Chang et al. (2008), konsumsi kedelai selama 4 minggu tidak menunjukkan penurunan total kolesterol yang berbeda nyata terhadap kelompok kontrol.

\section{KESIMPULAN}

Konsumsi tahu ungu selama 28 hari berpotensi dalam memperbaiki profil lipid darah penderita DM tipe-2 melalui penurunan kadar trigliserida, LDL, dan total kolesterol secara signifikan $(p<0,05)$, namun belum dapat memperbaiki kadar HDL pada subjek penderita diabetes.

\section{UCAPAN TERIMA KASIH}

Penulis mengucapkan terima kasih kepada subjek penelitian, kader, dan tokoh masyarakat yang terlibat, BOPTN Institut Pertanian Bogor, klinik dr. Katili, Darmaga, Bogor, serta PT Kreasi Inovasi Prosana yang mendanai penelitian ini.

\section{DAFTAR PUSTAKA}

Akter S, Rahman MM, Abe SK, Sultana K. 2014. Prevalence of diabetes and prediabetes and their risk factors among Bangladeshi adults: a nationwide survey. Bull World Health Organ (92):204-213A.

Bilous R, Donelly R. 2015. Buku Pegangan Diabetes Edisi Ke 4. 3-8. Jakarta: Bumi Medika.

Chang JH, Kim MS, Lii SS. 2008. Effects of soybean supplementation on blood glucose, plasma lipid levels, and erythtrocyte antioxidant enzyme activity in type 2 diabetes mellitus patients. Nutr Res Pract. 2(3):152157.

Dewi M, Khomsan A, Sukandar D. 2010. Intervensi kedelai tidak berpengaruh terhadap status inflamasi dan imunitas pada remaja dengan kegemukan. J Gizi Pangan. 5(1):15.

Effendi AT. 2013. Nutrigenomik resistensi insulin prediabetes. Cetakan 1. Bogor: IPB Press.

Koba S, Hirano T. 2011. Dyslipidemia and atherosclerosis. J Nihon Rinsho. 69(1):138143.

[IDF] International Diabetes Federation. 2015. Diabetes Atlas $7^{\text {th }}$ ed. Brussels.

Irwanto R, Zakaria FR, Adawiyah DR. 2016. Peran fisiologissari kedelai hitam diperka- 
ya mikroenkapsulan minyaksawit mentah pada penderita Diabetes Melitus Tipe-2. JTIP. 27(1):1-9.

Lameshow S, Hosmer Jr, Klar J, Lwanga SK. 1997. Besar Sampel dalam Penelitian Kesehatan. Yogyakarta: Gadjah Mada University Press.

Nelson LE, Valentine RJ, Cacicedeo JM, Gauthier MS, Ido Y, Ruderman NB. 2012. A novel inverse relationship between metformin-triggered AMPK-SRT1 signaling and p53 protein abundance in high glucoseexposed HepG2 cells. Am J Physiol Cell Physiol. 303(1):C4-C13.

Nizamutdinova IT, Jin YC, Chung JI, Shin SC, Lee SJ, Seo HG. 2009. The anti-diabetic effect of anthocyanins in streptozotocininduced diabetic rats through glucose transporter 4 regulation and prevention of insulin resistance and pancreatic apoptosis. Mol Nutr Food Res. 11:1419-1429.

Palanisamy N, Viswanathan $\mathrm{P}$, Anuradha CV. 2008. Effect of genistein, a soy isoflavone, on whole body insulin sensitivity and renal damage induced by a high-fructose diet. Renal Failure. 30: 645-54.

Putri NE. Rungkat-Zakaria F, Prangdimurti E. 2016. Pengaruh intervensi tahu kedelai hitam kaya serat terhadap glukosa darah dan inflamasi responden diabetes tipe-2. JTIP. 27(2):131-139.

Reynold K, Chin A, Lees KA, Nguyen A, Bujnowski D, He J. 2006. A meta analysis of the effect in healthy postmenopausal women. Am J Clin Nutr. 290:531-533.

Rafehi H, Ververis K, Karagiannis TC. 2012. Controversies surrounding the clinical potential of cinnamon for the management of diabetes: Review article. Diabetes Obes Metab. 14 :493-499.

Rucita A. 2012. Pengaruh pemberian yoghurt kedelai hitam (black soyghurt) terhadap kadar kolesterol LDL dan HDL pada penderita dyslipidemia (Artikel ilmiah). Semarang: Universitas Diponegoro.

Shrivastava A, Chaturvedi U, Bhatia G. 2013. Hypolipidemic and antioxidative effect of Lactobacillus acidophilus bacteria in hyperlipidemic rats. Asian J Pharm Clin Res 6(2):84-87.

Slamet R. 2011. Pengaruh pemberian yoghurt kedelai hitam (black soyghurt) terhadap profil lipid pada tikus hiperkolesterolemia (Artikel ilmiah). Semarang: Universitas
Diponegoro.

Triandita N, Zakaria-Rungkat F, Prangdimurti E, Putri NE. 2016. Perbaikan status antioksidan penderita diabetes tipe-2 dengan tahu kedelai hitam. J Teknol Ind Pangan. 27(2):123-130.

Tungland BC, Meyer D. 2002. Nondigestible oligo and polysaccarides (dietary fiber): their physiology and role in human health and food. CRFSFS. 3:90-109.

Ulbritch C, Saemon E. 2010. Natural standard herbal pharmacotheraphy. Missouri: Elsevier Inc. 187.

[WHO] World Health Organization. 2006. BMI Classification. http://apps.who.int/bmi/index.jsp?introPage $=$ intro_3.html. [Diakses 30 September 2015].

[WHO] World Health Organization. 2015. World Health Statistic. http://apps.who.int/iris/bitstream/10665/170250/1/9789240694439 eng.pdf?ua $=1 \& u a=1$. [diakses 30 september 2015).

Williamson DA, Geiselman PJ, lovejoy J, Greenway F, Volaufova J, Martin CK, Arnett C, Ortego L. 2006. Effects of consuming mycoprotein, tofu or chicken upon subsequent eating behaviour, hunger and safety. Appetite. 46:41-48.

Xu J, Eilat-Adar S, Loria C, Goldourt U, Howard BV, Fabsitz RR, Zephir EM, Mattil C, Lee ET. 2006. Dietary fat intaje and risk of coronary heart disease: the strong heart study. Am J Clin Nutr. 84:849-902.

Xu B, Chang K. 2008. Total phenolics, phenolic acids, isoflavones, and anthocyanins and antioxidant properties of yellow and blacksoybeans as affected by thermal processing. J Agric. Food Chem. 56:7165-7175.

Yulianti SR, Alwiyah M, Inggrid F. 2014. Profil pengobatan pasien diabetes mellitus tipe 2 di instalasi rawat inap RSUD Undata Palu tahun 2012. J. Natural Sci. 3(1):40-46.

Zakaria FR. 2015. Pangan nabati, utuh dan fungsional sebagai penyusun diet sehat untuk kesejahteraan masyarakat. Cetakan-1. Bogor: IPB Press. ISBN:978-979-493-923-9.

Zakaria FR, Firdaus DPR, Yuliana ND. 2016. Balck soybean tofu consumption for improving SGOT/SGPT and antioxidant activity of type-2 diabeteic respondent plasma. J Pangan. 25(2):95-104. 